Original Research

\title{
Surface Water Quality in the Mantaro River Watershed Assessed after the Cessation of Anthropogenic Activities Due to the COVID-19 Pandemic
}

\author{
María Custodio $^{1 *}$, Richard Peñaloza ${ }^{1}$, Juan Alvarado ${ }^{2}$, \\ Fernán Chanamé ${ }^{1}$, Edith Maldonado ${ }^{1}$ \\ ${ }^{1}$ Universidad Nacional del Centro del Perú, Centro de Investigación en Medicina de Altura y Medio ambiente, \\ Av. Mariscal Castilla N³909-4089, Huancayo, Perú \\ ${ }^{2}$ Universidad Nacional Intercultural "Fabiola Salazar Leguía” de Bagua, Jr. Comercio № 128, Bagua, Perú
}

Received: 5 August 2020

Accepted: 28 November 2020

\begin{abstract}
In late December 2019, the emerging disease COVID-19 was identified as a global pandemic. Countries around the world have implemented various types of blockades to stop this infection. These health measures have led to a significant reduction in air pollution. However, the impact of these measures on aquatic environments has been little analyzed. In this context, the water quality of rivers in the Mantaro River basin was evaluated using multivariate statistical methods and heavy metal contamination indices during the health crisis of the COVID-19 pandemic. Surface water samples were collected in triplicate from 15 sampling sectors at the end of the rainy season, between March and April. Concentrations of $\mathrm{Cu}, \mathrm{Fe}, \mathrm{Pb}, \mathrm{Zn}$ and $\mathrm{As}$ were determined by the method of atomic absorption flame spectrophotometry. The average concentrations of heavy metals and arsenic in the rivers evaluated did not exceed the environmental quality standards for drinking water of the Peruvian, WHO and US EPA regulations, except for $\mathrm{Pb}, \mathrm{Fe}$ and $\mathrm{As}$ in the Mantaro River and As in the Chia River. PCA presented a total variation percentage of $83.8 \%$. The results showed a clear positive relationship between the five heavy metals and metalloids. The hierarchical cluster analysis according to Spearman's correlation generated a dendrogram where the five chemical elements were grouped in two statistically significant groups, one group conglomerating to $\mathrm{Cu}, \mathrm{Pb}, \mathrm{Zn}$ and $\mathrm{Fe}$ and the other group to As. PERMANOVA partition shows that the spatial effects of the sectors are strong and significant. The HPI revealed that $13.33 \%$ of the sampling sectors exceeded the critical contamination value (150). The $\mathrm{C}_{\mathrm{d}}$ revealed low degree of contamination $(<1)$ in $86.67 \%$ of the sampling sectors
\end{abstract}

Keywords: water quality, watershed, Mantaro river, COVID-19 pandemic, health crisis

*e-mail: mcustodio@uncp.edu.pe 


\section{Introduction}

Aquatic systems are exposed to a variety of environmental pollutants, including heavy metals. Discharges of these pollutants into natural ecosystems are of great concern in today's society because of their inherent toxicity, persistence, non-degradability and tendency to accumulate in aquatic organisms [1] with implications for human health [2]. In addition, the release of trace metals from sediments into the water column is another source of contamination. Some metals, such as $\mathrm{Cd}, \mathrm{Pb}$, are carcinogenic and can bioaccumulate and biomagnify in fish and other aquatic organisms and can be transferred to humans through the food chain. Quantification of pollution and sources of pollutants are crucial for water resource management [3].

An emerging infectious disease called COVID-19 was identified in late December 2019 and has become a global pandemic [4-6]. Countries around the world have implemented various types of blockades to stop and mitigate this infection. Social isolation is one of them, with drastic effects on social and economic fronts. However, this blockade is leading to a rapid environmental recovery of the health status of ecosystems and air quality [7]. Satellite data published by the National Aeronautics and Space Administration (NASA) and the European Space Agency (ESA) indicate that pollution in some countries of the world has been reduced by up to 30 per cent, mainly nitrogen dioxide $\left(\mathrm{NO}_{2}\right)$ [8]. In Peru, after two months of obligatory social isolation decreed by the government as measures of protection, prevention and control of risks to contagion and deaths from SARS-CoV-2 (COVID-19), the water bodies have shown signs of recovery. To date, the waters of the Rímac River are crystal clear due to a $90 \%$ reduction in waste [9], at the close of operations of industrial activities and resilience driven by natural processes.

The central region of Peru is rich in mineral resources such as copper $(\mathrm{Cu})$, iron $(\mathrm{Fe})$, lead $(\mathrm{Pb})$, cobalt $(\mathrm{Co})$ and zinc $(\mathrm{Zn})$. In this region for several decades the extraction of minerals has been done by various mining units and most of the metals have been melted in the metallurgical center of the city La Oroya. Many of the mining units discharge their wastewater with high concentrations of toxic elements to water bodies causing pollution with repercussions on human health and ecosystems. Mantaro River water quality studies in 2007 showed high contents of $\mathrm{Pb}, \mathrm{Cd}, \mathrm{Hg}, \mathrm{Fe}$, $\mathrm{Cr}, \mathrm{Zn}, \mathrm{As}$ and cyanide [10], indicating that metals are the tracers of mining activity in this watershed. In 2018, the results of water quality monitoring in the Mantaro River watershed by the National Water Authority [11], revealed the persistence of high concentrations of some heavy metals and metalloids. Consequently, heavy metal contamination of water bodies in this basin remains one of the main environmental problems.

The Mantaro hydrographic system is composed of several bodies of water that are used for energy, agriculture, population, fish farming and mining, of great importance in the regional and national economy. The contamination of the Mantaro River with heavy metals and metalloids due to industrial activities, mainly mining, has restricted its use for human consumption $[12,13]$. The reduced availability of water in the low water season in the basin has led to the use of Mantaro River waters for agricultural irrigation and animal drinking. The use of these polluted waters affects soil quality, agricultural production, livestock and human health.

Monitoring of the water quality of the Mantaro River and some of its tributaries by the Peruvian National Water Authority has been carried out for several decades by conventional methods using physical and chemical parameters, mainly. Currently, there are several methods to characterize, analyze, evaluate and model water quality, from those using water quality indices to multivariate statistical methods [14]. The use of indices makes it possible to communicate the general condition of a body of water at a given place and time [15]. It helps monitoring programs to inform the general public and water managers of the state of the ecosystem. Multivariate statistical methods provide a detailed understanding of water quality through the interpretation of complex data matrices, facilitating the identification of potential sources of pollution [16].

In this context and considering that the industries that frequently discharged their wastewater to the water bodies of the Mantaro River Basin have reduced to fewer man-hours due to the national state of emergency against COVID-19. As well as the importance of water quality implications for human well-being and ecosystems, it becomes essential to answer the general question: What is the water quality of rivers in the Mantaro River basin using multivariate statistical methods and heavy metal contamination rates during the COVID-19 pandemic health crisis; as well as the specific questions: What is the concentration and distribution of heavy metals and arsenic in surface water of the Mantaro River basin? Are the results consistent with other recent findings on water quality in the Mantaro River and its tributaries, based on heavy metal and arsenic concentration levels, and what is the water quality based on multivariate statistical methods and heavy metal contamination indices? To answer these questions, the general objective of the study was: to evaluate the water quality of rivers in the Mantaro River basin using multivariate statistical methods and heavy metal contamination indexes during the health crisis of the COVID-19 pandemic, and as specific objectives: (1) analyze the concentration and distribution of heavy metals and arsenic in surface water of the Mantaro River basin; (2) compare the results obtained with other recent findings on water quality of the Mantaro River and its tributaries, according to the concentration levels of heavy metals and arsenic; (3) determine water quality according to multivariate statistical methods and indices of heavy metal contamination. 


\section{Materials and Methods}

\section{Study Area}

Mantaro River basin is located in the central Andes of Peru between the parallels $10^{\circ} 34^{\prime} 30^{\prime \prime}$ and $13^{\circ} 35^{\prime} 30^{\prime \prime}$ south latitude, and the meridians $73^{\circ} 55^{\prime} 00^{\prime \prime}$ and $76^{\circ} 40^{\prime} 30^{\prime \prime}$ west longitude. It has an area of $34,550.08 \mathrm{~km}^{2}$ and a complex topography that gives rise to a variety of climatic conditions. The Mantaro River is the main river in the basin. Its flow depends on rainfall throughout the basin, the level of Lake Junín, and the lakes located at the foot of the snow-capped mountains of the western mountain range and the snowcapped mountains of Huaytapallana. Its waters are used to develop a large number of activities, such as the irrigation of some 11,000 hectares of agricultural land [17].

The mean air temperature is lowest in July and highest in November. In areas above 4000 m.a.s.l., the temperature is around $4.3^{\circ} \mathrm{C}$, in areas between 3000 and 4000 m.a.s.l., the temperature varies between $8.1^{\circ} \mathrm{C}$ and $10.4^{\circ} \mathrm{C}$ and in areas between 2000 and 3000 m.a.s.1., the temperature varies between $14.6^{\circ} \mathrm{C}$ and $17.4^{\circ} \mathrm{C}$. The climate varies from semi-humid in a large part of the basin to very humid in the north-western and centraleastern part of the basin. Rainfall begins in July and gradually increases in August and September, being more significant from October until it reaches maximum values in February and March. In April, precipitation decreases sharply, reaching minimum values in June [18].

The rivers included in the study were chosen according to the characteristics of their environment and productive activities. The Chia River is characterized by its fish farming activities. The Cunas River is characterized by urban and agricultural activities developed along its banks. The river Shullcas, of glacial origin, is strongly influenced by the presence of large cities and small-scale agricultural activities in the last $8 \mathrm{~km}$ of its course. While, the Miraflores river along its course are small populations that are dedicated to subsistence agriculture. The Mantaro River, the main river in the watershed, has its own characteristics for each sector since its origin in Lake Junin. The sampling sectors were established according to their vulnerability to contamination, that is, according to industrial and municipal wastewater discharges, agricultural areas, tributary rivers, and urban areas. Three sampling sectors were established in the Mantaro River, Mant A, Mant B and Mant C, with seven, six and three sampling sites, respectively. The first sector (Mant A) was located downstream of the city of La Oroya, where the La Oroya metallurgical complex is located [19] with a length of $45 \mathrm{~km}$ The second sector (Mant B) with a length of $40 \mathrm{~km}$, includes an important part of the inter-Andean valley, whose primary activity is agricultural production for local consumption, national and export. The third

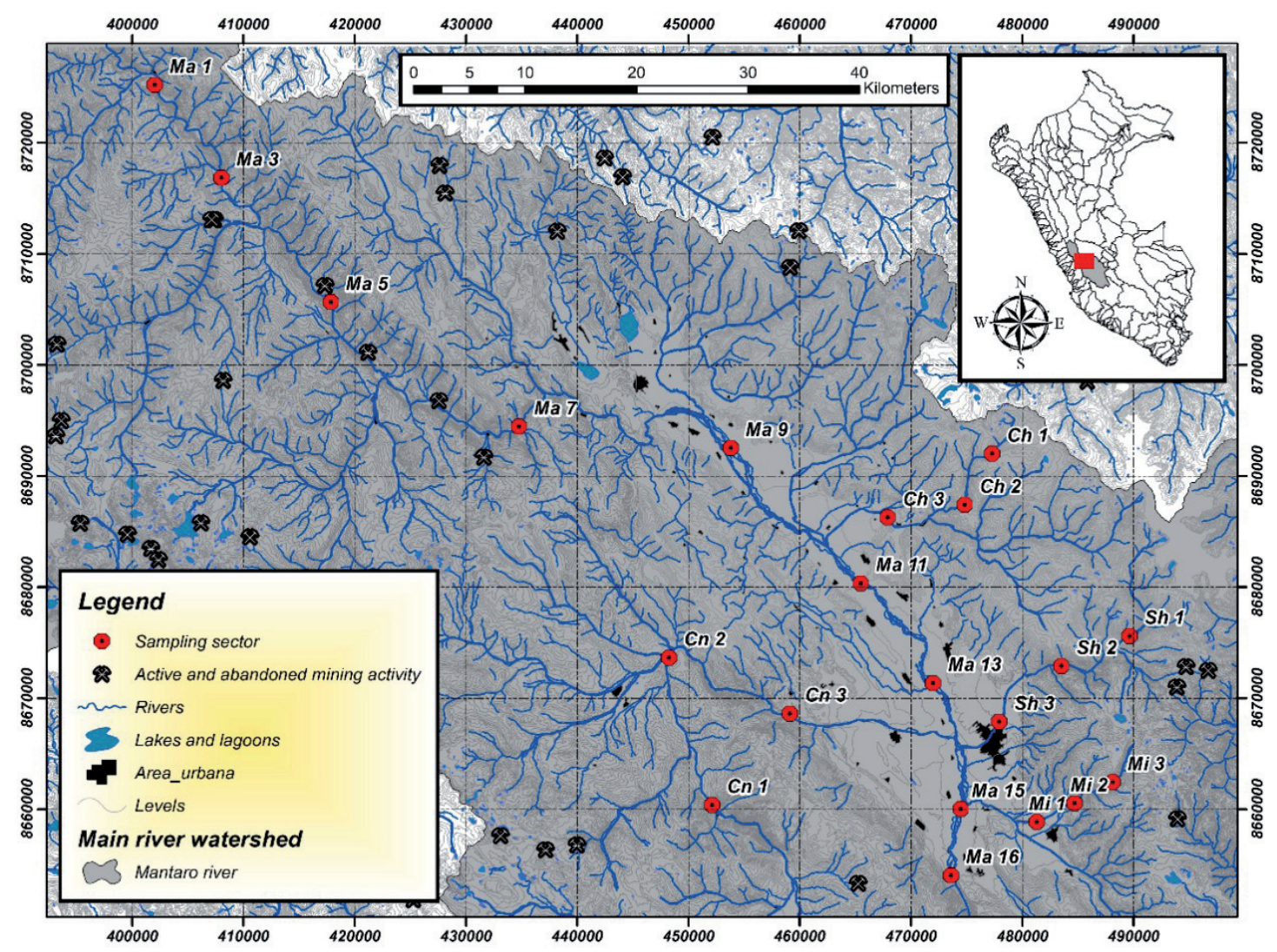

Fig. 1. Distribution of sampling sectors in rivers of the Mantaro River watershed in the central Peruvian Andes. 
sector (Mant C) has a length of $15 \mathrm{Km}$ and includes the consolidated urban area. In the Chia, Shullcas, Cunas and Miraflores tributaries three sampling sectors were established with their respective sampling sites (Fig. 1). These tributary rivers of the Mantaro River run through areas with important agricultural and fish farming activity, mainly. However, in the areas that these rivers cross, there are abandoned and active mining units, as well as consolidated urban settlements (Fig. 1).

\section{Collection and Analysis of Water Samples}

The sampling was done in established sectors of the Mantaro, Chia, Shullcas, Cunas, and Miraflores rivers in the Junin region, at the end of the rainy season, between March and April 2020. The water samples were obtained in the opposite direction to the flow of the current, about three meters from the shore and $20 \mathrm{~cm}$ from the surface of the water, in triplicate, in two-liter polyethylene bottles. Previously, the bottles were treated with a $10 \%$ nitric acid solution for 24 hours and rinsed with distilled water and water from the sampling sector, repeatedly. The conservation of each of the samples was achieved by adding $1.5 \mathrm{ml}$ of concentrated nitric acid to one litre of water [20]. All precautions were taken to minimize the risks of contamination during sample collection. Then, under refrigerated conditions, the samples were sent to the Water Research Laboratory of the National University of Central Peru for analytical determination.

The laboratory methods used for analytical determinations corresponded to those specified in the American Public Health Association's International Analytical Standards [21] and Food and Agriculture Organization of the United Nations [22]. The water samples were filtered using $0.45 \mu \mathrm{m}$ filters. The digestion of the samples was carried out from $250 \mathrm{ml}$ of water, brought to a boil to obtain $100 \mathrm{ml}$. Then, $5 \mathrm{ml}$ of nitric acid and $5 \mathrm{ml}$ of concentrated hydrochloric acid were added for the destruction of organic matter and again brought to a boil. It was left to cool and then $10 \mathrm{ml}$ of distilled water was added, filtered and measured in a $100 \mathrm{ml}$ phial, with $1 \%$ nitric acid. The concentration of $\mathrm{Cu}, \mathrm{Fe}, \mathrm{Pb}, \mathrm{Zn}$ and $\mathrm{As}\left(\mathrm{mg} \mathrm{L}^{-1}\right)$, was determined by the method of atomic absorption spectrophotometry by flame, using a Varian AA240 Atomic Absorption Spectrophotometer.

\section{Quality Control}

The analytical grade reagents and stock standard solutions were supplied by Merck (Germany). Double deionized water (Milli-Q System, Millipore) was used for the preparation of all solutions. The elemental standard solutions used for the calibration were prepared by diluting $1,000 \mathrm{mg} \mathrm{L^{-1 }}$ stock solutions of $\mathrm{Cu}, \mathrm{Pb}, \mathrm{Zn}, \mathrm{Fe}$ and As. From an average standard solution of $100 \mathrm{mg} \mathrm{L} \mathrm{L}^{-1}$, working standards 0.001 ; $0.01 ; 0.1 ; 1.0$ and $2.0 \mathrm{mg} \mathrm{L}^{-1}$ were prepared with $1 \%$ nitric acid. All glass materials used were cleaned by immersing them in dilute nitric acid for at least 24 hours. They were then rinsed with plenty of deionized water before use. The accuracy of the analytical procedures expressed as the relative standard deviation was less than 5\% for all metals analyzed by atomic absorption spectrophotometry. All analyses were performed in triplicate, and the results were expressed as the mean.

\section{Data Analysis}

\section{Statistical Analysis}

The k-R clustering technique (non-hierarchical) or flat clustering was used in the clustering analysis. It allowed a clustering with a desired number of clusters (k) in a meaningful way, based on the classical k-means clustering method. In addition, it seeks to minimize the sums of squares within the cluster, specific for Euclidean distance matrices, maximizing the similarity analysis (ANOSIM), which measures (non-parametrically) the degree of general separation of the k-groups, formed from the ranges in the fullsimilarity matrix [23], Spearman's non-parametric Rho was used for samples with non-normal distribution to test the correlations between the variables analyzed [24] ranging from ungrazed since 1979 to heavily grazed, at 540 sampling points to a depth of $0-4 \mathrm{~cm}$. Each sample was analysed for bulk density, organic carbon (OC. Principal component analysis (PCA) was used to explain the variance of a large data set of variables interrelated with a smaller set of independent variables. PCA provides information on the most significant parameters, which describe the entire data set, while allowing data reduction with minimal loss of original information [25, 26]. Annual and sector differences in heavy metal concentration were determined by an analysis of permutational multivariate variance (PERMANOVA) of two factors through a geometric partition of multivariate variation in the Euclidean dissimilarity space.

\section{Water Quality Indices}

Water quality has been determined by two indices, the heavy metal pollution index (HPI) and the pollution index based on the group averages determined by cluster analysis $\left(C_{d}\right)$.

\section{Heavy Metal Pollution Index (HPI)}

The HPI indicates the total quality of water with respect to heavy metals and is based on the arithmetic weighted average method. Initially, the classification scale is established for each selected parameter weight. Then, after selecting the pollution parameter on which 
the index should be based [27], the HPI is calculated using Equation (2).

$$
H P I=\sum_{i=1}^{n} W_{i} Q_{i} / \sum_{i=1}^{n} W_{i}
$$

...where, $\mathrm{Q}_{\mathrm{i}}=$ the parameter sub-index, $\mathrm{W}_{\mathrm{i}}=$ the parameter unit weight, $n=$ the number of parameters considered.

Sub index $\mathrm{Q}_{\mathrm{i}}$ of the parameter is calculated using Equation (3).

$$
Q_{i}=\sum_{i=1}^{n} \frac{M_{i}-I_{i}}{S_{i}-I_{i}} * 100
$$

...where, $\mathrm{M}_{\mathrm{i}}=$ the monitored heavy metal value of the parameter, $I_{i}=$ the ideal value of the parameter, $S_{i}=$ the standard value of the parameter.

An HPI value $<90$ indicates a low pollution degree, an HPI value from 90 to 150 indicates a medium pollution degree and an HPI value $>150$ indicates a high pollution degree.

\section{Contamination Index $\left(C_{d}\right)$}

$\mathrm{C}_{\mathrm{d}}$ evaluates water quality through the degree of contamination based on the number of parameters that exceed the upper permissible limit or guide values for potentially harmful elements and the concentration that exceeds these limit values [28]. $C_{d}$ is calculated using Equation (4) [29].

$$
C_{d} \sum_{i=1}^{n} C f i
$$

...where, $\mathrm{Cf}_{\mathrm{i}}=$ represents the pollutant factor for the $\mathrm{i}$-th component and is calculated using the equation (5).

$$
C f_{i}=\left(\frac{C A_{i}}{C N i}\right)-1
$$

...where $\mathrm{CA}_{\mathrm{i}}=$ analytical value of the $\mathrm{i}$-th component and $\mathrm{CN}_{\mathrm{i}}=$ upper permitted concentration of the $\mathrm{i}-\mathrm{h}$ component ( $\mathrm{N}$ denotes the normative value).

A $C_{d}$ value $<1$ indicates a low pollution degree, a $C_{d}$ value from 1 to 3 indicates a medium pollution degree and $\mathrm{C}_{\mathrm{d}}$ value $>3$ indicates a high contamination degree.

\section{Results}

\section{Analysis and Distribution of Heavy Metals and Arsenic in Surface Water}

Table 1 shows the mean and standard deviation of heavy metals and arsenic recorded in surface water of the Mantaro River basin during 2020, compared to data recorded in 2019 [30]. The results from both years show similar behavior of the rivers as a function of their average concentration of the elements evaluated. The results obtained in the Mant A sector of the
Mantaro and Shullcas rivers reveal a distribution of the mean concentration of heavy metals and arsenic in the descending order $\mathrm{Fe}>\mathrm{Zn}>\mathrm{As}>\mathrm{Cu}>\mathrm{Pb}$. In Chía and Cunas rivers the distribution of the mean concentration of metal species was in the descending order $\mathrm{Fe}>\mathrm{Zn}>\mathrm{As}>\mathrm{Cu}$. In the Miraflores river the distribution of the metallic species was of the order $\mathrm{Fe}>\mathrm{Zn}>\mathrm{Cu}$. The behavior of heavy metals and metalloids as a function of their mean concentration showed marked variability. In the Mantaro River, the Man A sector showed the highest mean concentrations of heavy metals and arsenic. The mean concentration of $\mathrm{Fe}$ varied from $9.50 \mu \mathrm{g} \mathrm{L}^{-1}$ in the Cunas River to $671.10 \mu \mathrm{g} \mathrm{L}^{-1}$ in the Mantaro River Mant A sector in 2019 and from $19.33 \mu \mathrm{g} \mathrm{L}^{-1}$ to $493.70 \mu \mathrm{g} \mathrm{L}^{-1}$ in the same water bodies, in 2020. Similar behavior was presented by the $\mathrm{Zn}$ for these two rivers. The mean concentration of the As fluctuated from $1.67 \mu \mathrm{g} \mathrm{L}^{-1}$ in the Shullcas River to $20.75 \mu \mathrm{g} \mathrm{L}^{-1}$ in the Mant A sector of the Mantaro River in 2019, maintaining this trend in 2020. This same distribution trend showed the mean $\mathrm{Cu}$ and $\mathrm{Pb}$ concentrations in the Shullcas and Mantaro rivers in 2019 and 2020.

In the three sectors of the Mantaro River the mean concentration of these metallic elements was higher than that registered in the other rivers in both years. Fe presented the highest concentrations in all the sampling sectors, exceeding the environmental quality standards (EQS) $\left(300 \mu \mathrm{g} \mathrm{L}^{-1}\right)$ of Peru, referred to water for human consumption [31]. As well as the WHO drinking water guidelines $\left(300 \mu \mathrm{g} \mathrm{L}^{-1}\right)$ [32] and U.S. Environmental Protection Agency drinking water standards [US EPA] $\left(300 \mu \mathrm{g} \mathrm{L}^{-1}\right)$ [33]. However, they did not exceed the environmental quality standards (EQS) for irrigation water $\left(5 \times 10^{3} \mu \mathrm{g} \mathrm{L}^{-1}\right)$. In the Chia, Cunas, Shullcas and Miraflores rivers during 2019 and 2020, the mean concentration of $\mathrm{Fe}$ did not exceed national or international standards, except for the Miraflores river in 2020 .

The mean zinc concentrations in the rivers evaluated did not exceed the national EQS for drinking water production $\left(3 \times 10^{3} \quad \mu \mathrm{g} \quad \mathrm{L}^{-1}\right)$ and irrigation $\left(2 \times 10^{3} \mu \mathrm{g} \mathrm{L}^{-1}\right)$. They also did not exceed the WHO drinking water guidelines $\left(3 \times 10^{3} \mu \mathrm{g} \mathrm{L}^{-1}\right)$ or the US EPA drinking water standards $\left(5 \times 10^{3} \mu \mathrm{g} \mathrm{L}^{-1}\right)$. The highest concentrations of this metal were recorded in the Mantaro River, which receives a large number of tributary rivers that flow through areas with mining influence and industrial and municipal effluents. The mean concentration of As in $40 \%$ the rivers evaluated did not exceed the values of the EQS for water intended for human consumption in Peru $(10 \mu \mathrm{g}$ $\mathrm{L}^{-1}$ ), nor the WHO guidelines for drinking water, except in the Chia River. In this river the mean concentration of As greatly exceeded the Peruvian water EQS and the threshold values established by the WHO and EPA $\left(10 \mu \mathrm{g} \mathrm{L}^{-1}\right)$.

The mean $\mathrm{Cu}$ concentrations recorded in the five rivers in the study did not exceed the EQS for water 
Table 1. Mean and standard deviation (SD) of heavy metals and arsenic recorded in surface water of the Mantaro River basin in the central Andes of Peru $\left(\mu \mathrm{g} \mathrm{L}^{-1}\right)$.

\begin{tabular}{|c|c|c|c|c|c|c|c|c|c|c|c|c|c|c|c|c|}
\hline Sector & $\begin{array}{c}\text { Descriptive } \\
\text { statistics }\end{array}$ & \multicolumn{3}{|c|}{$\mathrm{Cu}$} & \multicolumn{3}{|c|}{$\mathrm{Pb}$} & \multicolumn{3}{|c|}{$\mathrm{Zn}$} & \multicolumn{3}{|c|}{$\mathrm{Fe}$} & \multicolumn{3}{|c|}{ As } \\
\hline \multirow{2}{*}{$\begin{array}{c}\text { Mant A / } \\
\text { 2019* }\end{array}$} & Mean $\pm \mathrm{DE}$ & 16.24 & \pm & 4.69 & 12.81 & \pm & 2.97 & 76.83 & \pm & 9.71 & 671.10 & \pm & 151.70 & 20.75 & \pm & 5.83 \\
\hline & Rank & 11.00 & - & 24.70 & 6.60 & - & 15.00 & 66.50 & - & 94.00 & 470.90 & - & 841.00 & 11.96 & - & 26.57 \\
\hline \multirow{2}{*}{$\begin{array}{c}\text { Mant A / } \\
2020\end{array}$} & Mean $\pm \mathrm{DE}$ & 11.04 & \pm & 4.38 & 13.67 & \pm & 4.99 & 70.14 & \pm & 18.41 & 493.70 & \pm & 108.40 & 20.50 & \pm & 3.96 \\
\hline & Rank & 7.00 & - & 17.40 & 7.60 & - & 22.00 & 48.00 & - & 10.80 & 167.00 & - & 489.00 & 15.00 & - & 26.06 \\
\hline \multirow{2}{*}{$\begin{array}{c}\text { Mant B / } \\
\text { 2019* }\end{array}$} & Mean $\pm \mathrm{DE}$ & 11.80 & \pm & 4.33 & 10.48 & \pm & 3.94 & 60.62 & \pm & 6.38 & 560.00 & \pm & 290.00 & 11.08 & \pm & 3.12 \\
\hline & Rank & 5.57 & - & 18.80 & 6.00 & - & 16.30 & 55.60 & - & 73.00 & 212.00 & - & 935.00 & 7.21 & - & 15.77 \\
\hline \multirow{2}{*}{$\begin{array}{c}\text { Mant B / } \\
2020\end{array}$} & Mean $\pm \mathrm{DE}$ & 7.50 & \pm & 1.05 & 6.50 & \pm & 1.76 & 74.33 & \pm & 24.20 & 423.00 & \pm & 94.50 & 11.50 & \pm & 1.05 \\
\hline & Rank & 6.00 & - & 9.00 & 5.00 & - & 9.00 & 48.00 & - & 112.00 & 265.00 & - & 503.00 & 10.00 & - & 13.00 \\
\hline \multirow{2}{*}{$\begin{array}{c}\text { Mant C / } \\
2019^{*}\end{array}$} & Mean $\pm \mathrm{DE}$ & 9.95 & \pm & 2.91 & 10.60 & \pm & 2.60 & 47.50 & \pm & 6.74 & 681.20 & \pm & 70.80 & 13.75 & \pm & 2.57 \\
\hline & Rank & 8.04 & - & 13.30 & 7.60 & - & 12.20 & 41.50 & - & 54.80 & 615.10 & - & 756.00 & 10.81 & - & 15.55 \\
\hline \multirow{2}{*}{$\begin{array}{c}\text { Mant C / } \\
2020\end{array}$} & Mean $\pm \mathrm{DE}$ & 8.33 & \pm & 2.08 & 6.33 & \pm & 2.08 & 69.30 & \pm & 22.50 & 338.00 & \pm & 119.90 & 13.67 & \pm & 2.08 \\
\hline & Rank & 6.00 & - & 10.00 & 4.00 & - & 8.00 & 50.00 & - & 94.00 & 241.00 & - & 472.00 & 12.00 & - & 16.00 \\
\hline \multirow{2}{*}{ Chia / 2019* } & Mean $\pm \mathrm{DE}$ & 1.37 & \pm & 0.06 & 0 & \pm & 0 & 15.30 & \pm & 0.30 & 14.40 & \pm & 4.40 & 14.33 & \pm & 1.53 \\
\hline & Rank & 1.30 & - & 1.40 & 0 & - & 0 & 15.00 & - & 15.60 & 10.00 & - & 18.80 & 13.00 & - & 16.00 \\
\hline \multirow{2}{*}{ Chia / 2020} & Mean $\pm \mathrm{DE}$ & 1.57 & \pm & 0.51 & 2.33 & \pm & 1.16 & 11.00 & \pm & 1.73 & 34.33 & \pm & 15.28 & 15.00 & \pm & 5.00 \\
\hline & Rank & 1.00 & - & 2.00 & 1 & - & 3 & 10.00 & - & 13.00 & 21.00 & - & 51.00 & 10.00 & - & 20.00 \\
\hline \multirow{2}{*}{ Cun / 2019* } & Mean $\pm \mathrm{DE}$ & 1.90 & \pm & 0.20 & 0 & \pm & 0 & 9.30 & \pm & 0.80 & 9.50 & \pm & 2.40 & 8.00 & \pm & 1.00 \\
\hline & Rank & 1.70 & - & 2.10 & 0 & - & 0 & 8.50 & - & 10.10 & 7.10 & - & 11.90 & 7.00 & - & 9.00 \\
\hline \multirow{2}{*}{ Cun / 2020} & Mean $\pm \mathrm{DE}$ & 1.00 & \pm & 0 & 0 & \pm & 0 & 13.00 & \pm & 3.61 & 19.33 & \pm & 4.16 & 1.67 & \pm & 0.58 \\
\hline & Rank & 1.00 & - & 1.00 & 0 & - & 0 & 10.00 & - & 17.00 & 16.00 & - & 24.00 & 1.00 & - & 2.00 \\
\hline \multirow{2}{*}{ Mir / 2019} & Mean $\pm \mathrm{DE}$ & 1.70 & \pm & 0.10 & 0 & \pm & 0 & 11.20 & \pm & 0.60 & 183.20 & \pm & 5.20 & 0 & \pm & 0 \\
\hline & Rank & 1.60 & - & 1.80 & 0 & - & 0 & 10.60 & - & 11.80 & 178.00 & - & 188.40 & 0 & - & 0 \\
\hline \multirow{2}{*}{ Mir / 2020} & Mean $\pm \mathrm{DE}$ & 1.27 & \pm & 0.25 & 0 & \pm & 0 & 12.00 & \pm & 2.00 & 452.70 & \pm & 56.50 & 2.00 & \pm & 1.00 \\
\hline & Rank & 1.00 & - & 1.50 & 0 & - & 0 & 10.00 & - & 14.00 & 397.00 & - & 510.00 & 1.00 & - & 3.00 \\
\hline \multirow{2}{*}{$\begin{array}{l}\text { Shull / } \\
\text { 2019* }\end{array}$} & Mean $\pm \mathrm{DE}$ & 1.13 & \pm & 0.15 & 0.73 & \pm & 0.06 & 13.30 & \pm & 1.50 & 91.00 & \pm & 4.70 & 1.67 & \pm & 1.16 \\
\hline & Rank & 1.00 & - & 1.30 & 0.70 & - & 0.80 & 11.80 & - & 14.80 & 86.30 & - & 95.70 & 1.00 & - & 3.00 \\
\hline \multirow{2}{*}{ Shull / 2020} & Mean $\pm \mathrm{DE}$ & 6.33 & \pm & 1.53 & 2.33 & \pm & 2.08 & 17.00 & \pm & 8.89 & 95.70 & \pm & 77.80 & 2.00 & \pm & 1.00 \\
\hline & Rank & 5.00 & - & 8.00 & 0.00 & - & 4.00 & 10.00 & - & 27.00 & 25.00 & - & 179.00 & 1.00 & - & 3.00 \\
\hline \multicolumn{17}{|c|}{ Peruvian } \\
\hline \multicolumn{2}{|c|}{ Drinking water EQS } & \multicolumn{3}{|c|}{$2 \times 10^{3}$} & \multicolumn{3}{|c|}{10} & & $\mathrm{x} 1$ & & & 300 & & & 10 & \\
\hline Water for & rrigation & & 200 & & & 50 & & & $\mathrm{x} 1$ & & & $x 10^{3}$ & & & 100 & \\
\hline & & & & & & & WHC & & & & & & & & & \\
\hline $\begin{array}{r}\text { Drinking w } \\
\text { lin }\end{array}$ & ter guide- & & $x 10$ & & & 10 & & & $\mathrm{x} 1$ & & & 300 & & & 10 & \\
\hline & & & & & & & USEP & & & & & & & & & \\
\hline Drinking Wat & er Standards & & $\mathrm{x} 10$ & & & 0.0 & & & $\mathrm{x} 1$ & & & 300 & & & 0.0 & \\
\hline
\end{tabular}

*Data shared by Custodio et al. 
Table 2. Principal component loads (Varimax standardization) for metals in water.

\begin{tabular}{|c|c|c|c|c|c|}
\hline Element & PC 1 & PC 2 & PC 3 & PC 4 & PC 5 \\
\hline $\mathrm{Cu}$ & -0.454 & 0.023 & -0.823 & 0.325 & -0.1 \\
\hline $\mathrm{Pb}$ & -0.476 & 0.147 & 0.108 & -0.141 & 0.849 \\
\hline $\mathrm{Zn}$ & -0.472 & -0.144 & -0.011 & -0.788 & -0.369 \\
\hline $\mathrm{Fe}$ & -0.411 & -0.713 & 0.381 & 0.412 & -0.088 \\
\hline $\mathrm{As}$ & -0.419 & 0.67 & 0.407 & 0.289 & -0.355 \\
\hline Eigen values & 3.61 & 0.584 & 0.335 & 0.251 & 0.225 \\
\hline \% variance & 72.1 & 11.7 & 6.7 & 5 & 4.5 \\
\hline Cumulative & 72.1 & 83.8 & 90.5 & 95.5 & 100 \\
\hline
\end{tabular}

from Peru intended for drinking water production $\left(2 \times 10^{3} \mu \mathrm{g} \mathrm{L}^{-1}\right)$ and irrigation $\left(200 \mu \mathrm{g} \mathrm{L}^{-1}\right)$, nor did they exceed the WHO drinking water guidelines $\left(2 \times 10^{3} \mu \mathrm{g} \mathrm{L}^{-1}\right)$ and US EPA drinking water standards $\left(1 \times 10^{3} \mu \mathrm{g} \mathrm{L}^{-1}\right)$. The highest mean $\mathrm{Cu}$ concentration was recorded in the Mantaro River followed by the mean $\mathrm{Cu}$ concentrations of the Cunas, Miraflores, Chia and Shullcas Rivers. The mean $\mathrm{Pb}$ concentration in $80 \%$ of the rivers under study did not exceed the EQS for water $\left(10 \mu \mathrm{g} \mathrm{L}^{-1}\right)$ in Peru. In the Mantaro River, all three sectors evaluated during 2019 exceeded Peru's EQS and WHO drinking water guidelines. In 2020, only the Mant A sector exceeded these standards and guidelines. The high standard deviation value revealed that the $\mathrm{Pb}$ concentration in some sampling sectors of this river exceeded the Peruvian and WHO water EQS.

Principal component analysis (PCA) is a powerful technique that allows the dimensionality of a data set to be reduced in such a way as to highlight similarities and differences [34, 35]. PCA generated five main components and showed that only two factors were necessary for the Eigen values, with values above 0.5, which represents $83.8 \%$ of the total variance. The first component explains $72.1 \%$ of the total variance with strong loads of $\mathrm{Cu}, \mathrm{Pb}$ and $\mathrm{Zn}$, elements that trace anthropogenic activities associated with mining and smelting in the evaluated sectors. In addition, these results highlight the contamination of nearly 100 years of operation of the metallurgical complex La Oroya. However, the joint location of these trace elements probably also indicates the geochemical nature and soil heterogeneity. The second component explains $11.7 \%$ of the total variance, with high As and Fe loads; a result that reflects the possible contributions of anthropogenic and lithogenic activities.

Fig. 2 shows the principal component analysis (PCA) of the 2020 sampling sectors and its comparison with the 2019 results. This analysis reveals significant differences between the tributary rivers and the Mantaro River sectors with respect to the concentration of $\mathrm{Pb}, \mathrm{Cu}$ and $\mathrm{Zn}$. Meanwhile, As and $\mathrm{Fe}$, although they vary in the rivers evaluated, their significance value is minimal. The Mant A sector included the sampling sectors located near the La Oroya metallurgical complex, which had higher concentrations of $\mathrm{Pb}$, As and $\mathrm{Cu}$. The Mant B sector included the sampling sectors located $52 \mathrm{~km}$ from the Mant A sector, which had lower concentrations of heavy metals and metalloids, except for $\mathrm{Zn}$. The sector Mant C, located $80 \mathrm{Km}$ from the sector Mant A showed a similar behavior to the sector Mant B regarding the concentrations of the elements evaluated. However, this group contains the highest concentrations of $\mathrm{Fe}$ and $\mathrm{Zn}$ for both years. PCA

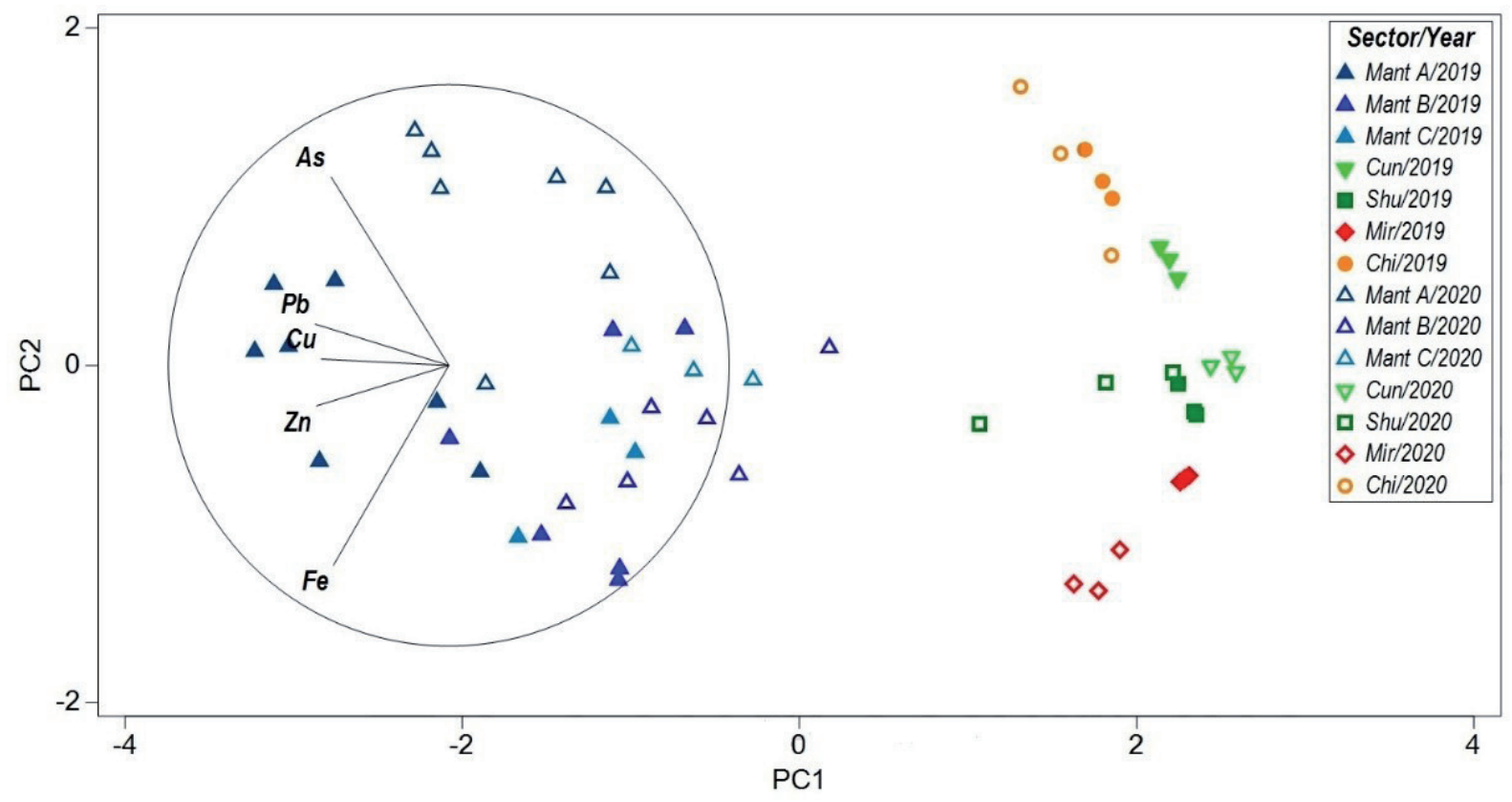

Fig. 2. Perceptual map of principal component analysis of sampling sectors based on cluster analysis. 
indicates that as the course of the river moves away from the main source of contamination which is the La Oroya metallurgical complex and the Cerro de Pasco mine, the concentrations of $\mathrm{Cu}, \mathrm{Pb}$ and As decrease, but the concentrations of $\mathrm{Fe}$ and $\mathrm{Zn}$ increase. However, along the entire course of the Mantaro River, $\mathrm{Pb}$ is a constant concentration element. The sectors of tributary rivers present chemical behaviors different from the sectors of the Mantaro River. The Cunas and Chia rivers run through agricultural and fish farming areas respectively. The Shullcas and Miraflores rivers have characteristics of disturbance typical of urban areas with effects of sanitary landfill and solid waste storage. Therefore, the first main component (CP 1) is weighted for sectors with metallurgical mining pressure and CP 2 varies its distribution according to the pressure of agricultural, urban and fish farming activities. These results also reveal that the effect of the health emergency context by COVID-19 on the concentrations of heavy metals and As assessed do not reflect a significant decrease.

$\mathrm{K} R$ cluster analysis has been successfully applied in numerous studies to group sampling sites with similar characteristics, process and sources [36, 37]. The AC was conducted to pool similar water samples in the Mantaro River basin based on heavy metal and arsenic concentrations obtained during the COVID-19 pandemic health crisis. Fig. 3 shows the k R clustering overlaid on the AC. The SIMPROF routine has completed the procedure with $\mathrm{k}=2$ groups (with an $\mathrm{R}$ of 0.92 at a significance level of $5 \%$ ), which groups 56 sampling sites into 2 statistically significant groups. Group 1 (A) grouped $43 \%$ of the sampling sites of the Cunas, Chia, Shullcas and Miraflores rivers, characterized by being tributaries of the Mantaro river and having similar characteristics. Group 2 (B) grouped $57 \%$ of the Mantaro River sampling sites. The clustering of sampling sites shown by the $\mathrm{k} R$ cluster results indicates the significant spatial variation of heavy metal and As concentrations in the Mantaro River groups. These results also reveal the opportunity to design a future spatial sampling strategy in an optimal way in this basin and to propose a water monitoring program that will strengthen the monitoring carried out by the Peruvian National Water Authority.

The hierarchical cluster analysis as a function of Spearman's correlation in Fig. 4 generated a dendrogram where the five chemical elements were grouped into two statistically significant groups, one group conglomerating to $\mathrm{Cu}, \mathrm{Pb}, \mathrm{Zn}$ and $\mathrm{Fe}$ and the other group to As. The group containing the heavy metals has concentrations consistent with their distribution across the sectors evaluated. The highest concentrations of heavy metals were recorded in the Mant A, B and C sectors and the lowest concentrations in the tributary river sectors, maintaining a constant distribution as shown in Fig. 4B). The results also show a highly significant correlation between these elements according to Spearman's analysis (Fig. 4A). The rho for the correlation pairs of $\mathrm{Cu}$ with $\mathrm{Pb}, \mathrm{Zn}, \mathrm{Fe}$, and $\mathrm{As}$ were $0.80,0.73,0.63$ and 0.58 respectively. The rho for the pairs of $\mathrm{Pb}$ with $\mathrm{Zn}, \mathrm{Fe}$ and As were 0.76, 0.66 and 0.71 respectively; for the case of $\mathrm{Zn}$ its rho values for its pairs $\mathrm{Fe}$ and As were 0.62 and 0.60 respectively. While the rho for Fe with As was 0.41. These results showed a strong association/interaction between the metals in the different sampling sectors, revealing a strong dependence on the causal factor. The contribution of heavy metals and As to the waters of the rivers evaluated comes from metallurgical activities, mining, agricultural runoff, urban activities and transport, mainly. However, they probably also come from the natural crust, as natural geological processes play an important role in the contribution of heavy metals and metalloids [38].

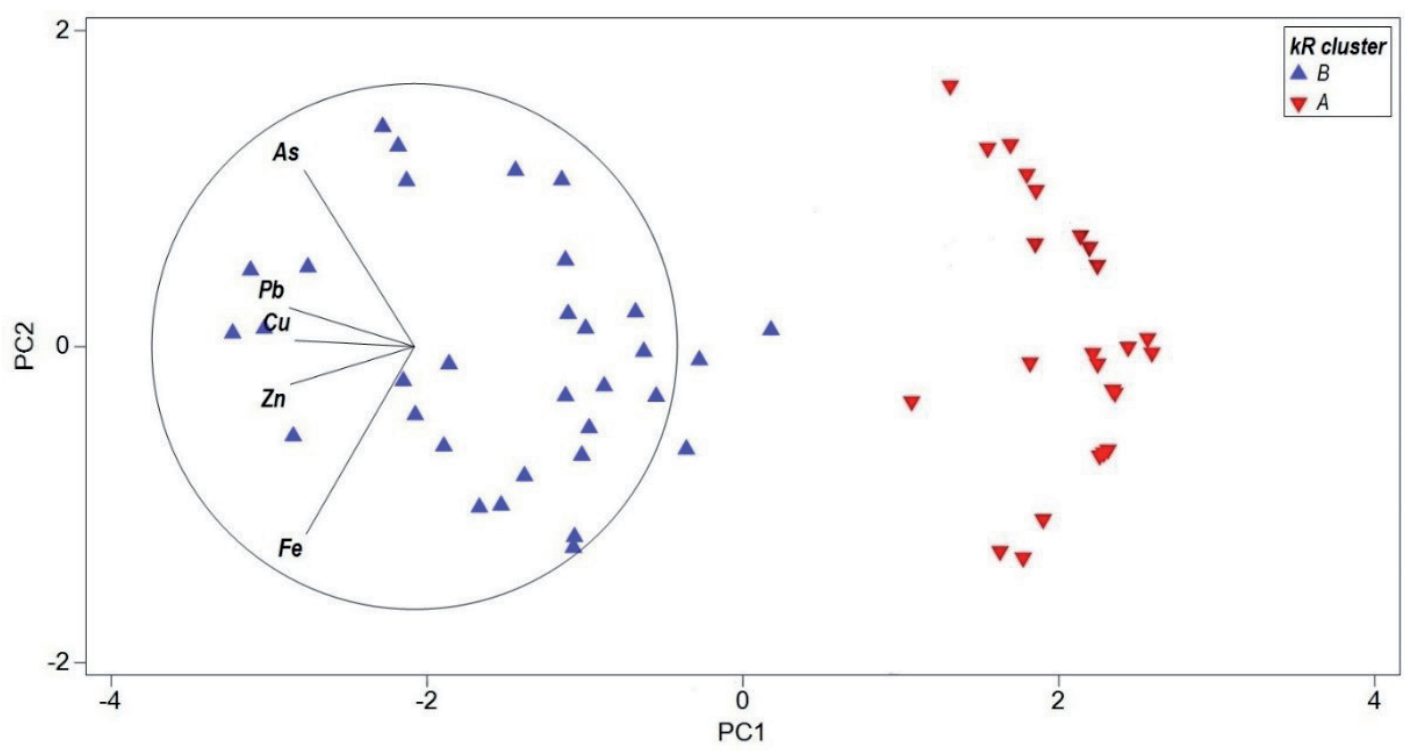

Fig. 3. k-R clustering $(\alpha=0.05)$ in scatter diagram of principal components of metals in water for Mantaro river basin by sector and year. 


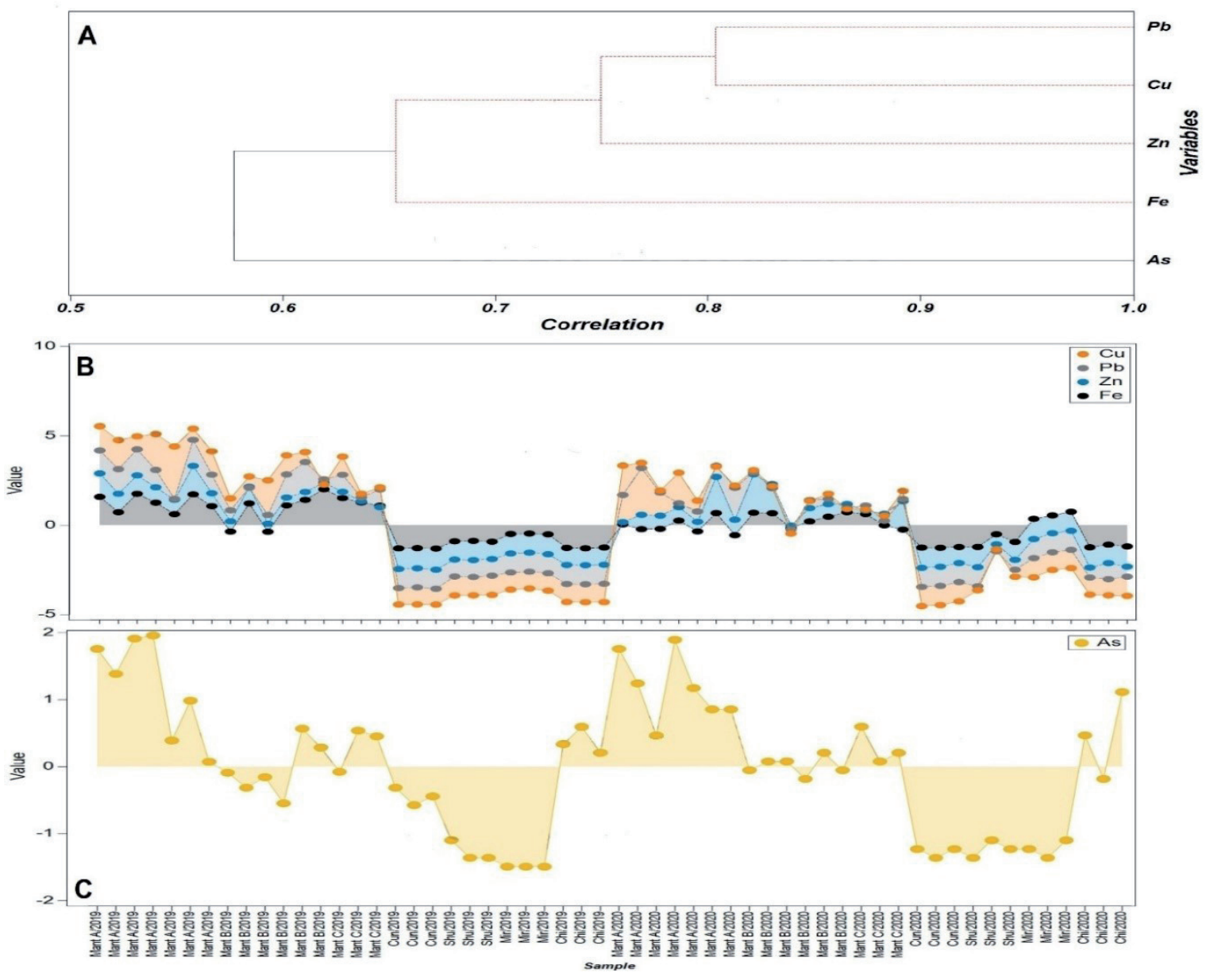

Fig. 4. Spearman correlation dendrogram and distribution of heavy metal concentration in river water by sectors and years.

Despite finding a significant correlation between the elements $(p<0.05)$, some tended to be more analogous to others, such as $\mathrm{Cu}, \mathrm{Pb}, \mathrm{Zn}$ and $\mathrm{Fe}$. The correlation analysis in dendrogram 4A shows the As with different distribution tendencies in the sampling sectors; since their rho values were low despite being significant. Fig. 4C shows the distribution of As across all sectors evaluated for the year 2020, with a decrease in the sectors of the Cunas river. This behavior is due to the decrease in mining extraction activities in some areas as a result of the mandatory social immobilization adopted by the Peruvian government to curb COVID-19. While the Chía and Mat B sectors of the Mantaro River located in agricultural areas and the Mat $\mathrm{C}$ sector of the Mantaro River located in densely populated urban areas showed an increase in their arsenic concentrations.

PERMANOVA partition shows that the spatial effects of the sectors are strong and significant, matching the larger variation components of the PCA. Small-scale spatial-temporal variation was also identifiable from statistically significant interactions $(p<0.05)$. The effects of sectors per year varied, as is the case for the Mantaro River, especially sectors A and B for both years (Table 3, p <0.05). According to the
PCA, the effects of the proximity to the metallurgical zone are the strongest, especially contrasting the areas of slag deposits sub product of mining, with higher concentrations of Fe. In addition, it is observed that for both years the tributary rivers did not significantly modify their concentrations of elements, denoting a low effect of the activities close to these sectors.

The results of this study as an effect of the obligatory social immobilization and partial paralysis of the mining industry in the Mantaro River basin would only be reflected in the Mantaro River's Mant A and Mantaro River's B sectors (Table 4, $\mathrm{p}<0.05$ ), since only in these sectors the concentrations of the elements evaluated significantly decreased. These results are also evident along axis 2 of the GPA (from 2019 to 2020). In the case of the tributary rivers, there were no significant changes in their metallic concentrations at a multivariate level, reflecting the relative sizes of these main effects in the partition of PERMANOVA: sector and year of sampling. The PCA graph not only shows the same pattern, but also shows that the spatial effects (along CP 1) are much larger in sectors near metallurgical mining centers. The pair-wise comparisons further support these general conclusions. 
Table 3. PERMANOVA pair wise test in term 'Sector*Year' for pairs levels factor 'Sector'.

\begin{tabular}{|c|c|c|c|c|c|c|c|}
\hline \multicolumn{8}{|c|}{ Within level ,2019' of factor ,Year'(t/P(pem)) } \\
\hline & Mant A & Mant B & Mant C & Cun & Shu & Mir & Chi \\
\hline Mant A & & 0.007 & 0.004 & 0.01 & 0.01 & 0.008 & 0.016 \\
\hline Mant B & 2.134 & & 0.605 & 0.012 & 0.014 & 0.009 & 0.005 \\
\hline Mant C & 2.0592 & 0.84166 & & 0.107 & 0.1 & 0.102 & 0.102 \\
\hline Cun & 6.267 & 4.2006 & 7.9725 & & 0.11 & 0.105 & 0.101 \\
\hline Shu & 6.4059 & 4.1074 & 7.8319 & 7.6459 & & 0.095 & 0.09 \\
\hline Mir & 6.4047 & 4.0578 & 7.8127 & 16.109 & 5.1496 & & 0.109 \\
\hline Chi & 5.9193 & 4.1279 & 7.5927 & 6.0868 & 11.403 & 17.376 & \\
\hline \multicolumn{8}{|c|}{ Within level ,2020' of factor, Year' (t/P(pem)) } \\
\hline & Mant A & Mant B & Mant C & Cun & Shu & Mir & Chi \\
\hline Mant A & & 0.001 & 0.58 & 0.008 & 0.01 & 0.009 & 0.006 \\
\hline Mant B & 2.7302 & & 0.704 & 0.01 & 0.01 & 0.02 & 0.012 \\
\hline Mant C & 1.734 & 0.70879 & & 0.087 & 0.093 & 0.113 & 0.086 \\
\hline Cun & 5.1475 & 5.9979 & 5.4505 & & 0.096 & 0.118 & 0.105 \\
\hline Shu & 4.2282 & 4.4986 & 3.7491 & 2.7584 & & 0.102 & 0.113 \\
\hline Mir & 4.9509 & 5.0887 & 4.8581 & 10.775 & 4.295 & & 0.108 \\
\hline Chi & 3.8869 & 4.8262 & 3.7666 & 4.3997 & 3.4912 & 5.7865 & \\
\hline
\end{tabular}

\section{Assessment of Water Quality Through Pollution Indices}

Table 5 shows the existing contamination levels through the HPI and $\mathrm{Cd}$ indexes categorized according to Kwaya et al. (2019) [29] compared according to the groups defined by the sampling sector and year of evaluation. The HPI value for the Mant A sector based on WHO and EPA quality standards exceeds the critical values of 150 for 2019 and 2020. This result indicates that the Mantaro River Mant A sector has a high degree of contamination, followed by the Mant $\mathrm{B}$ and Mant $\mathrm{C}$ sectors that presented an intermediate HPI with a tendency to decrease the concentrations

Table 4. PERMANOVA pair wise test in term 'Sector*Year' for pairs levels factor 'Years 2019-2020'.

\begin{tabular}{|c|c|c|}
\hline Sector & $\mathrm{t}$ & $\mathrm{P}($ perm $)$ \\
\hline Mant A & 2.1663 & $0.003^{* *}$ \\
\hline Mant B & 1.6342 & $0.016^{*}$ \\
\hline Mant C & 2.0966 & 0.097 \\
\hline Cun & 7.4015 & 0.094 \\
\hline Shu & 2.4126 & 0.11 \\
\hline Mir & 7.3691 & 0.097 \\
\hline Chi & 1.0646 & 0.612 \\
\hline
\end{tabular}

of elements according to the course of the Mantaro River. Most of the sectors of the tributary rivers have low HPI values. However, the sectors of the Chía, Miraflores and Shullcas rivers present HPI values with a tendency to increase year by year. In contrast, the sectors of the Cunas River showed low HPI values. The contamination index $(\mathrm{Cd})$ calculated for the elements of $\mathrm{Pb}$ and $\mathrm{As}$ are high only in the Mantaro River sector A with indexes above or close to 1, indicating that they are high risk according to WHO. While according to the EPA regulations these contamination indexes of these elements are at the limit, but tend to decrease along the river. While for the other sectors of the tributary rivers there are no traces of these elements or they are insignificant according to the regulation of both organisms. In general terms, the concentrations of heavy metals and As evaluated in the Mantaro River basin have average pollution rates, and that tributaries are responsible for reducing these concentrations along their course.

\section{Discussion}

Analysis and Distribution of Heavy Metals and Arsenic in Surface Water

The World Health Organization in January 2020 declared a global public health emergency due to the rapid spread of the new coronavirus (SARS-CoV2). 
Table 5. Heavy metal and arsenic contamination indices in river water in the Mantaro River watershed.

\begin{tabular}{|c|c|c|c|c|}
\hline Sector & HPIa & $\mathrm{HPIb}$ & $\mathrm{Cda}$ & $\mathrm{Cdb}$ \\
\hline Mant A/2019 & 168.034 & 167.736 & 1.356 & 0.929 \\
\hline Mant A/2020 & 168.967 & 168.666 & 1.417 & 0.961 \\
\hline Mant B/2019 & 108.652 & 108.460 & 0.156 & -0.193 \\
\hline Mant B/2020 & 90.470 & 90.308 & -0.200 & -0.417 \\
\hline Mant C/2019 & 122.976 & 122.758 & 0.435 & 0.082 \\
\hline Mant C/2020 & 99.803 & 99.625 & -0.001 & -0.212 \\
\hline Chia /2019 & 70.282 & 70.156 & -0.567 & -0.567 \\
\hline Chia / 2020 & 85.084 & 84.932 & -0.267 & -0.344 \\
\hline Cun /2019 & 39.236 & 39.166 & -1.200 & -1.200 \\
\hline Cun $/ 2020$ & 8.271 & 8.256 & -1.833 & -1.833 \\
\hline Mir/2019 & 0.998 & 0.996 & -2.000 & -2.000 \\
\hline $\mathrm{Mir} / 2020$ & 12.260 & 12.238 & -1.800 & -1.800 \\
\hline Shull/2019 & 12.251 & 12.229 & -1.760 & -1.784 \\
\hline Shull/2020 & 21.731 & 21.693 & -1.567 & -1.645 \\
\hline Average 2019 & 74.633 & 74.500 & -0.511 & -0.676 \\
\hline Average 2020 & 69.512 & 69.388 & -0.607 & -0.756 \\
\hline
\end{tabular}

a. Based in WHO standar

b. Based in EPA standar

Currently, almost all countries are trying to stop the spread of this virus by establishing public policies of isolation and social distancing. In this period of a few months of abiding by health restrictions, the world has changed, giving rise to unexpected consequences, such as the notable fall in the consumption of fossil fuels with positive effects on air quality $[39,40]$ and the recovery of water transparency due to the significant reduction in anthropogenic pressures, as has been observed in the waters of the Venice canals, Italy [41].

In Peru, as in other parts of the world, the usual human activities, industries, and vehicle and air transport were stopped in response to the measures taken by the Peruvian government in the face of the COVID-19 pandemic health crisis. Consequently, the indirect impact of the coronavirus (SARS-CoV2) on the environment in Peruvian territory has been little analyzed. This exceptional circumstance provides an opportunity to corroborate claims that industry and human activities cause damage to the environment [42]. Because of this, it was important to monitor the behavior of toxic metals in surface water during the first month of obligatory social isolation decreed in Peruvian territory and the total paralysis of some industries and partial paralysis of others, such as mining.

In the Mantaro River watershed, most of the water bodies are used for energy, agriculture, population, fish farming and mining, which are of great importance in the national and regional economy. However, many of these water bodies show signs of heavy metal contamination. In the Mantaro River, the main river in the basin, high concentrations of heavy metals and metalloids have been recorded that exceed the environmental quality standards for water in the Peruvian standard and the threshold values of WHO and US EPA. However, in this study the concentrations of these metallic contaminants are lower in most of the sectors evaluated than those registered by Custodio et al. (2020) [30] in this same river basin in April 2019, where activities were regular.

The distribution of heavy metals in surface water is influenced by natural and anthropogenic factors [43]. Fe was the element that recorded the highest concentrations in the rivers studied. This result would be influenced by the contribution of $\mathrm{Fe}$ containing minerals from sedimentary rocks of the Andean Mesozoic belt in the Peruvian Andes [44] and anthropogenic sources of Fe, such as corrosive iron materials, leachates and industrial and municipal wastewater. These results are supported by Kumar et al. (2017) [45] indicating that Fe values above water quality standards are generally associated with anthropogenic sources. Fe is a metal with biological importance for the normal development of cellular processes [46]. However, high concentrations can negatively affect living beings by generating reactive oxygen species [47].

$\mathrm{Cu}$ is an essential micronutrient that every living organism needs for growth and is required as a key element in many biological processes as a cofactor for numerous enzymes. In humans, low concentrations of $\mathrm{Cu}$ can result in incomplete development, and high concentrations can trigger gastrointestinal problems, hemolysis, hemoglobinuria, liver necrosis, cardiotoxicity, tachycardia, tachypnea, and central nervous system-related effects [48]. In the environment $\mathrm{Cu}$ is found in a wide range of mineral deposits, either in its pure or compound form [49]. In the aquatic environment $\mathrm{Cu}$ concentrations often increase due to the input of wastewater from industrial and domestic activities. In this study the Mantaro River recorded the highest $\mathrm{Cu}$ concentrations with values far exceeding values recorded in other parts of the world [50, 51] which indicate that lethal $\mathrm{Cu}$ effects are observed in several groups of aquatic invertebrates from $5 \mu \mathrm{g} / \mathrm{L}$.

$\mathrm{Zn}$ is one of the most common elements in the earth's crust, it is found in air, soil and water and is present in all foods. It is one of the oldest known trace elements and a common contaminant that is widely distributed in the aquatic environment [52-54]. In these environments, high concentrations of $\mathrm{Zn}$ have been shown to be toxic to aquatic organisms. In humans, this metal has low toxicity, but if consumed over a long period of time it can constitute a health risk, causing fatigue, dizziness, and neutropenia $[55,56]$. Prolonged oral exposure to $\mathrm{Zn}$ may interfere with essential $\mathrm{Cu}$ metabolism which may result in hematological and gastrointestinal effects [57]. The concentrations of $\mathrm{Fe}, \mathrm{Cu}$ and $\mathrm{Zn}$ recorded 
in the rivers studied were in the range of national and international water quality standards evidencing the effect of the quarantine shutdown of most industrial activities. These results are supported by Goher et al. [58] reporting that soil erosion and atmospheric adsorption can add heavy metals to water bodies, significantly.

$\mathrm{Pb}$ is a heavy metal that is found as metallic lead in nature, in the forms divalent $\left(\mathrm{Pb}^{2+}\right)$ and tetravalent $\left(\mathrm{Pb}^{4+}\right) \cdot \mathrm{Pb}^{2+}$ salt is soluble in water and its high content in the aquatic environment is toxic to aquatic biota. In humans, a number of studies have shown that lead can seriously damage the nervous system (mental retardation and related dysfunctional diseases), blood, reproductive and renal systems, particularly in children [59]. As well as other natural minerals, ace tends to circulate in the environment. In aquatic environments, the most thermodynamically stable form of As is the pentavalent $\mathrm{As}(\mathrm{V})$ that forms arsenate [60]. In waters highly affected by industrial pollution, the formation of organic As occurs through microbial activity (of some bacteria and fungi) that can induce some biomethanization phenomena (addition of $\mathrm{CH} 3$-arsenic) leading to the formation of monomethylarsonic acid, dimethylarsinic acid and trimethylarsinic oxide, mainly [61]. The values of $\mathrm{Pb}$ and $\mathrm{As}$ exceeded the maximum permissible values of national and international standards were recorded, revealing that this river has been experiencing strong anthropogenic pressure, such as industrial water discharges from mining-metallurgical activities, glassware and ceramics, tanning, insecticides, metal coatings, among others.

\section{Assessment of Water Quality through Contamination Indices}

The increasing deterioration of water quality has led to the development of various indices to assess the effects of human interventions, including pollution indices for heavy metals and the degree of contamination. The results obtained with the use of these indices reveal the great influence of the metals studied on the general quality of the Mantaro River water. This behavior would be influenced by processes of mineralization of the basin, mining, industrial activities, vehicle fleet, agriculture, among others. The mean value of the contamination index (HPI) for the studied rivers, both tributary and main river of the basin, in all its sectors, qualified as waters with a medium contamination degree. In general, the water quality of the rivers in the Mantaro River Basin is moderately acceptable according to the WHO indices. The results of HPI in the rivers studied showed lower values than those obtained for these metals by Kwaya et al. Based on US EPA indices, the Mantaro River waters show high HPI values and indicate that the waters are contaminated by the toxic metals included in the study. The mean contamination degree $\left(\mathrm{C}_{\mathrm{d}}\right)$ values calculated according to WHO and US EPA standards exhibited lower values revealing that the study area has low heavy metal contamination. In general, the behavior of toxic metals in surface water is complex and is a function of anthropogenic interventions. This is corroborated by the results obtained in this study during the period of cessation of much of the human activities by the pandemic COVID-2019, which show a slight reduction in concentrations of heavy metals and As in most sectors of sampling compared to the study conducted in these bodies of water in the Mantaro River basin during 2019 .

\section{Conclusions}

The rivers of the Mantaro River watershed provide an important source of water for the populations of large cities in the central region of Peru. Anthropogenic activities such as mining, agriculture and other industrial activities have an impact on water quality. The values of heavy metal and As content in most of the rivers studied during the period of mandatory isolation and cessation of industrial activities established by the Peruvian government due to the COVID-19 pandemic showed values lower than national and international standards and those recorded in studies during 2019 in this river watershed.

With respect to national and international standards, $\mathrm{As}$ and $\mathrm{Pb}$ are the most serious pollutants involved in carcinogenic problems. In addition, the toxic metals were separated spatially, as the highest concentrations were recorded in the sectors of the Mantaro River. Therefore, controlling the discharge of pollutants, improving the treatment of industrial and domestic wastewater, and strengthening monitoring in the Mantaro River watershed can be of great importance to restore the health of surface water bodies and reduce the risk of the population to exposure to toxic metals.

\section{Conflict of Interest}

The authors declare no conflict of interest.

\section{Acknowledgements}

We thank the Water Research Laboratory of the Universidad Nacional del Centro del Peru for allowing us to use their equipment and materials to carry out the sampling phase.

\section{References}

1. MILAČIČ R., ZULIANI T., VIDMAR J., OPRČKAL P., ŠČANČAR J. Potentially toxic elements in water and sediments of the Sava River under extreme flow events. Sci. Total Environ. 605-606, 894, 2017. 
2. OVIEDO R., MOÍNA-QUIMÍ E., NARANJO-MORÁN J., BARCOS-ARIAS M. Heavy metal contamination in southern Ecuador associated with mining activity. Bionatura 2 (4), 437, 2017.

3. WANG J., LIU G., LIU H., LAM, P.K. Multivariate statistical evaluation of dissolved trace elements and a water quality assessment in the middle reaches of Huaihe River, Anhui, China. Sci. Total Environ. 583, 421, 2017.

4. CHEN N., ZHOU M., DONG X., QU J., GONG F., HAN Y., QIU Y., WANG J., LIU Y., WEI Y., XIA J., YU T., ZHANG X., ZHANG L. Epidemiological and clinical characteristics of 99 cases of 2019 novel coronavirus pneumonia in Wuhan, China: a descriptive study. Lancet 395 (10223), 507, 2020.

5. LI Q., GUAN X., WU P., WANG X., ZHOU L., TONG Y., REN R., LEUNG K.S., LAU E.H., WONG J.Y., XING X., XIANG N., WU Y., LI C., CHEN Q., LI D., LIU T., ZHAO J., LIU M., TU W., CHEN C., JIN L., YANG R., WANG Q., ZHOU S., WANG R., LIU H., LUO Y., LIU Y., SHAO G., LI H., TAO Z., YANG Y., DENG Z., LIU B., MA Z., ZHANG Y., SHI G., LAM T.T., WU J.T., GAO G.F., COWLING B.J., YANG B., LEUNG G.M., FENG Z. Early transmission dynamics in Wuhan, China, of novel coronavirus-infected pneumonia. N. Engl. J. Med. 382 (13), 1199, 2020

6. WORLD HEALTH ORGANIZATION. Coronavirus disease 2019 (COVID-19) Situation Report-72, 2020.

7. SAADAT S., RAWTANI D., MUSTANSAR C. Environmental perspective of COVID-19. Sci. Total Environ. J. 728, 1, 2020.

8. MUHAMMAD S., LONG X., SALMAN M. COVID-19 pandemic and environmental pollution: A blessing in disguise? Sci. Total Environ. 728, 138820, 2020.

9. NATIONAL WATER AUTHORITY. Rimac River has crystalline waters after reduction of waste by $90 \%$ during quarantine Gestión 2020. Gestión Newsp. 2020.

10. ENVIRONMENTAL DIALOGUE BUREAU. Environmental quality assessment of water and soil resources. Huancayo, 2007.

11. NATIONAL WATER AUTHORITY. Participatory monitoring of water quality in Lake Chinchaycocha (flood season) Junin-Pasco. 2014.

12. MINISTRY OF ENVIRONMENT. Identification of pollution sources in the Mantaro River watershed. 2009.

13. US EPA. Recreational Water Quality Criteria. 2012.

14. BENGRAÏNE K., MARHABA T.F. Using principal component analysis to monitor spatial and temporal changes in water quality. J. Hazard. Mater. 100, 179, 2003.

15. HOWLADAR M.F., AL NUMANBAKTH M.A., FARUQUE M.O. An application of Water Quality Index (WQI) and multivariate statistics to evaluate the water quality around Maddhapara Granite Mining Industrial Area, Dinajpur, Bangladesh. Environ. Syst. Res. 6, 1, 2018.

16. BHUYAN M.S., BAKAR, M.A., AKHTAR A., HOSSAIN M.B., ALI M.M., ISLAM, M.S. Heavy metal contamination in surface water and sediment of the Meghna River, Bangladesh. Environ. Nanotechnology, Monit. Manag. 8, 273, 2017.

17. MINISTRY OF AGRICULTURE. Assessment of surface water resources in the Mantaro River watershed. 2010.

18. AVALOS G., ORLA C., JÁCOME G., ACUÑA D., LLACZA A., CUBAS, F. Climate change in the Mantaro river basin. MINEN, 2013.

19. REUER M., BOWER N., KOBALL J., HINOSTROZA E., DE LA TORRE M., HURTADO A., ECHEVARRÍA S.
Lead, arsenic and cadmium contamination and its impact on childrens health in La Oroya, Perú. Int. Sch. Res. Netw. 2012, 1, 2012.

20. MINISTRY OF HEALTH. Protocol for monitoring the sanitary quality of surface water resources. 2007.

21. APHA Standard Methods for Examination of Water and Wastewater (Standard Methods for the Examination of Water and Wastewater). in American Public Health Association (APHA): Washington, DC, USA, 2012.

22. FAO. Compilation of legal limits for hazardous substances in fish and fishery product. 1983.

23. DING C., HE X. K-means Clustering via Principal Component Analysis. in 21st International Confer- ence on Machine Learning, Banff, Canada. 2004.

24. STEFFENS M., KÖLBL A., TOTSCHE K.U., KÖGELKNABNER I. Grazing effects on soil chemical and physical properties in a semiarid steppe of Inner Mongolia (P.R. China). Geoderma 143 (1-2), 63, 2008.

25. MONTOYA S.O. Application of the factorial analysis to the investigation of markets. Case of study. Sci. Tech. $\mathbf{3}$ (35), 281, 2007.

26. GIRI S., KUMAR A. Assessment of Surface Water Quality Using Heavy Metal Pollution Index in Subarnarekha River, India. Water Qual Expo Health 5, 173, 2014.

27. ABD H., HEGAZY T. Evaluation of Water Quality Pollution Indices for Groundwater Resources of New Damietta , Egypt. MOJ Ecol. Environ. Sci. 2 (6), 1, 2017.

28. BACKMAN B., BODIŠ D., LAHERMO P., RAPANT S., TARVAINEN T. Application of a groundwater contamination index in Finland and Slovakia. Environ. Geol. 36, 55, 1998.

29. KWAYA Y., HAMIDU H., MOHAMMED A.I., ABDULMUMINI Y.N., ADAMU H., GREMA H.M., DAUDA M., BELLO HALILU F., KANA, A.M. Heavy Metals Pollution Indices and Multivariate Statistical Evaluation of Groundwater Quality of Maru town and environs. J. Mater. Environ. Sci. 10 (1), 32, 2019.

30. CUSTODIO M., ÁlvAREZ D., CUADRADO W., MONTALVO R., OCHOA S. Potentially toxic metals and metalloids in surface water intended for human consumption and other uses in the Mantaro River watershed, Peru. Soil Water Res. 2020 (1), 1, 2020

31. MINEN. Approve Environmental Quality Standards for Water and establish complementary provisions. El Peruano. Off. Newsp. 6, 2017.

32. WHO. Guidelines for drinking-water quality, fourth edition. WHO, 2011.

33. US EPA. National recommended water quality criteria. Environmental Protection Agency, Office of water. 2006.

34. REHMAN QAISAR F.U., ZHANG F., PANT R.R., WANG G., KHAN S., ZENG C. Spatial variation, source identification, and quality assessment of surface water geochemical composition in the Indus River Basin, Pakistan. Environ. Sci. Pollut. Res. 25 (13), 12749, 2018.

35. PANT R.R., ZHANG F., REHMAN F.U., KOIRALA M., RIJAL K., MASKEY R. Spatiotemporal characterization of dissolved trace elements in the Gandaki River, Central Himalaya Nepal. J. Hazard. Mater 389, 121913, 2020.

36. BARAKAT A., EL M., RAIS J., AGHEZZAF B., SLASSI M. International Soil and Water Conservation Research Assessment of spatial and seasonal water quality variation of Oum Er Rbia River (Morocco) using multivariate statistical techniques. Int. Soil Water Conserv. Res. 4 (4), 284, 2016. 
37. PACHECO C.R., PACHECO A.J., YE M., CABRERA S.A. Groundwater Quality: Analysis of Its Temporal and Spatial Variability in a Karst Aquifer. Groundwater 56 (1), 62, 2018.

38. BARONAS J., TORRES M., CLARK K., WEST A. Mixing as a driver of temporal variations in river hydrochemistry: 2. Major and trace element concentration dynamics in the Andes-Amazon transition. Water Resour. Res. 53, 3120, 2017.

39. ZAMBRANO-MONSERRATE M.A., RUANO M.A., SANCHEZ-ALCALDE L. Indirect effects of COVID-19 on the environment. Sci. Total Environ. 728, 138813, 2020.

40. GAUTAM S. The Influence of COVID-19 on Air Quality in India: A Boon or Inutile. Bull. Environ. Contam. Toxicol. 104 (6), 724, 2020.

41. BRAGA F., SCARPA G.M., BRANDO V.E., MANFÈ G., ZAGGIA L. COVID-19 lockdown measures reveal human impact on water transparency in the Venice Lagoon. Sci. Total Environ. 736, 139612, 2020.

42. YUNUS A.P., MASAGO Y., HIJIOKA Y. COVID-19 and surface water quality: Improved lake water quality during the lockdown. Sci. Total Environ. 731, 139012, 2020.

43. SOJKA M., JASKULA J., SIEPAK, M. Heavy metals in bottom sediments of reservoirs in the lowland area of western Poland: Concentrations, distribution, sources and ecological risk. Water (Switzerland) 11 (1), 1, 2018.

44. PETERSEN U. Regional geology and major ore deposits of central Peru. Econ. Geol. 60 (3), 407, 1965.

45. KUMAR V., BHARTI P.K., TALWAR M., TYAGI A.K., KUMAR P. Studies on high iron content in water resources of Moradabad district (UP), India. Water Sci. 31 (1), 44, 2017.

46. LOZOFF B. Early Iron Deficiency Has Brain and Behavior Effects Consistent with Dopaminergic Dysfunction. J. Nutr. 141 (4), 740S, 2011.

47. ZUCCA F.A., SEGURA A.J., FERRARI E., MUÑOZ P., PARIS I., SULZER, D., SARNA T., CASELLA L., ZECCA L. Interactions of iron, dopamine and neuromelanin pathways in brain aging and Parkinson's disease. Physiol. Behav. 176 (1), 100, 2016.

48. DESAI V., KALER S.G. Role of copper in human neurological disorders. Am. J. Clin. Nutr. 88 (3), 855, 2008.

49. DIAMI S.M., KUSIN F.M., MADZIN Z. Potential ecological and human health risks of heavy metals in surface soils associated with iron ore mining in Pahang, Malaysia. Environ. Sci. Pollut. Res. 23 (20), 21086, 2016.

50. ISLAM M.S., AHMED M.K., RAKNUZZAMAN M., HABIBULLAH -AL- MAMUN M., ISLAM M.K. Heavy metal pollution in surface water and sediment: A preliminary assessment of an urban river in a developing country. Ecol. Indic. 48, 282, 2015.

51. RAJESHKUMAR S., LIU Y., ZHANG X., RAVIKUMAR B., BAI G., LI X. Studies on seasonal pollution of heavy metals in water, sediment, fish and oyster from the
Meiliang Bay of Taihu Lake in China. Chemosphere 191, 626, 2018.

52. TAWEEL A., SHUHAIMI-OTHMAN M., AHMAD A.K. Assessment of heavy metals in tilapia fish (Oreochromis niloticus) from the Langat River and Engineering Lake in Bangi, Malaysia, and evaluation of the health risk from tilapia consumption. Ecotoxicol. Environ. Saf. 93, 45, 2013.

53. KUANG C., SHAN Y., GU J., SHAO H., ZHANG W., ZHANG Y., ZHANG J., LIU H Assessment of heavy metal contamination in water body and riverbed sediments of the Yanghe River in the Bohai Sea, China. Environ. Earth Sci. 75, 14, 2016.

54. PANDEY L.K., PARK J., SON D.H., KIM W., ISLAM M.S., CHOI S., HOJUN L., HAN T. Assessment of metal contamination in water and sediments from major rivers in South Korea from 2008 to 2015. Sci. Total Environ. 651, 323, 2019.

55. LIU C., ZHANG J., LI F., YANG J., QIU Z., CAI Y., ZHU L., XIAO M., WU Z. Trace elements spatial distribution characteristics, risk assessment and potential source identification in surface water from Honghu Lake, China. J. Cent. South Univ. 25 (7), 1598, 2018.

56. SALEH H.N., PANAHANDE M., YOUSEFI M., ASGHARI F.B., OLIVERI CONTI G., TALAEE E., MOHAMMADI A.A. Carcinogenic and Non-carcinogenic Risk Assessment of Heavy Metals in Groundwater Wells in Neyshabur Plain, Iran. Biol. Trace Elem. Res. 190 (1), 251, 2019.

57. FAKHRI, Y., SAHA, N., GHANBARI, S., RASOULI, M., MIRI, A., AVAZPOUR, M., RAHIMIZADEH A., RIAHI S., GHADERPOORI M., KERAMATI H., BIGARD M., AMINADAZ N., MOUSAVI KHANEGHAH, A. Carcinogenic and non-carcinogenic health risks of metal(oid)s in tap water from Ilam city, Iran. Food Chem. Toxicol. 118, 204, 2018.

58. GOHER M.E., ALI M.H.H., EL-SAYED S.M. Heavy metals contents in Nasser Lake and the Nile River, Egypt: An overview. Egypt. J. Aquat. Res. 45 (4), 301, 2019.

59. WONGSASULUK P., CHOTPANTARAT S., SIRIWONG W., ROBSON M. Heavy metal contamination and human health risk assessment in drinking water from shallow groundwater wells in an agricultural area in Ubon Ratchathani province, Thailand. Environ. Geochem. Health 36 (1), 169, 2014.

60. CUBADDA F., JACKSON B., COTTINGHAM K., VAN HOME Y., KURZIUS-SPENCER, M. Human exposure to dietary inorganic arsenic and other arsenic species: State of knowledge, gaps and uncertainties. Sci. Total Env. 579,1228, 2017.

61. JAISHANKAR M., TSETEN T., ANBALAGAN N., MATHEW B.B., BEEREGOWDA K.N. Toxicity, mechanism and health effects of some heavy metals. Interdiscip. Toxicol. 7 (2), 60, 2014. 